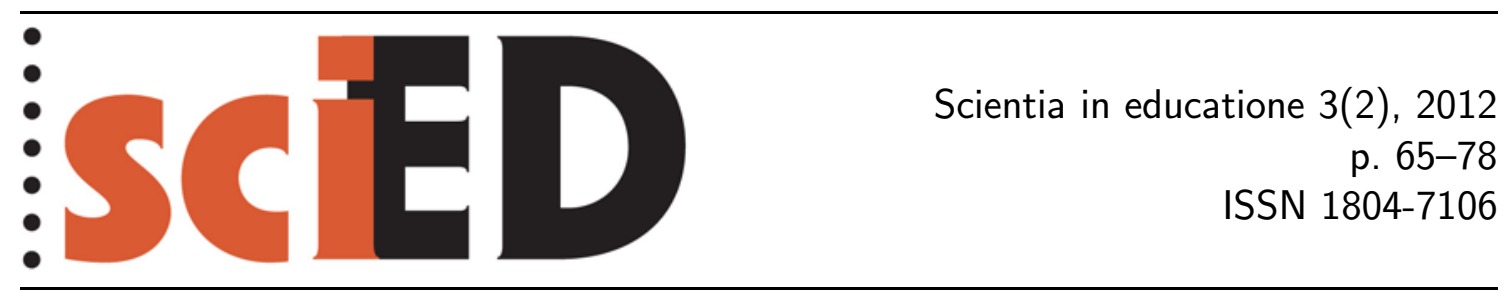

\title{
Faktory ovlivňující postoje studentů gymnázií k vyučovacímu předmětu chemie
}

\author{
Kateřina Švandová, Milan Kubiatko
}

\begin{abstract}
Abstrakt
Předkládaná studie je zaměřena na výzkum postojů studentů českých gymnázií k vyučovacímu předmětu chemie. Klade si za cíl zjistit zejména rozdíl v postojích z hlediska pohlaví, navštěvovaného ročníku a oblíbeného předmětu. Jako výzkumný nástroj byl použit dotazník s pětistupňovými škálovanými položkami Likertova typu, který byl administrován 552 studentům čtyř českých gymnázií. Pomocí faktorové analýzy byly položky rozděleny do čtyř kategorií: 1. Významnost chemie, 2. Oblíbenost a náročnost chemie, 3. Chemické pomůcky a laboratorní experimenty, 4. Zájem o chemii. Celkové skóre postojové části indikovalo neutrální postoj studentů k vyučovacímu předmětu chemie. Mezi chlapci a dívkami byl rozdíl ve skóre ve prospěch chlapců, s pozitivním postojem, a to v porovnání s dívkami, které již chemii vnímají neutrálně. Studenti prvního ročníku vnímají chemii neutrálně, s narůstajícím věkem studentů je patrný pokles, kdy se postoje k chemii stávají negativními, a to jak u studentů druhého, tak i třetího ročníku. V závěru jsou navrženy možnosti dalšího směřování výzkumu v této oblasti.
\end{abstract}

Klíčová slova: chemie, dotazník, postoje, studenti gymnázií.

\section{Factors Influencing the Secondary School Students' Attitudes to Chemistry}

\begin{abstract}
The study is focused on the investigation of students' attitudes to the subject of Chemistry on Czech secondary grammar schools. The partial aims are to find out differences between results with respect to gender, year of study and favourite subject. A questionnaire with 5point Likert type items was used as a research tool. The sample size contained 552 Czech secondary grammar school students. By factor analysis the items were distributed into four categories: 1 . The relevance of chemistry, 2. Popularity and difficulty of chemistry, 3. Chemical aids and laboratory experiments, 4. Interest in chemistry. The overall score indicated neutral students' attitudes toward chemistry. There was a statistically significant difference between boys and girls. Boys achieved higher score in comparison with girls. Boys perceived chemistry positively and girls neutrally. The youngest students perceived chemistry positively, others had neutral attitude toward chemistry. The conclusion includes further possibilities of research in this area.
\end{abstract}

Key words: chemistry, questionnaire, attitudes, grammar school students. 


\section{1 ÚVOD}

Postoje $\mathrm{k}$ přírodovědným předmětům a jejich zkoumání řadíme $\mathrm{v}$ dnešní době mezi důležité výzkumné oblasti, a to zejména kvůli vzájemnému vztahu mezi postoji studentů $\mathrm{k}$ předmětu a jejich úspěšností v tomto předmětu. Ani chemie není v tomto směru výjimkou. Tento vzájemný vztah byl již ve světě potvrzen různými výzkumnými šetřeními, mezi která můžeme zahrnout studie od autorů Cheung (2009), Kan a Akbas (2006) a Salta a Tzougraki (2004), kteří uvádějí, že mezi postoji studentů $\mathrm{k}$ chemii a úspěšností studentů v tomto předmětu je pozitivní vliv (stanovený hodnotou korelace vyšší než 0,50$)$. Kromě pozitivního vztahu mezi postoji a úspěšností, je jedním z dalších důvodů, proč by měly být rozvíjeny pozitivní postoje k chemii, vybrání povolání v oblasti chemie pro budoucí život.

Předkládaná studie poukazuje na vnímání studia chemie studenty ${ }^{1}$ gymnázií v České republice. Kapitola „Teoretická východiska“ nastiňuje podobu chápání postojů v obecné rovině a též stručně shrnuje současný stav řešené problematiky se zaměřením na zjištování postojů žáků a studentů $\mathrm{k}$ vyučovacímu předmětu chemie. Metodická část je věnována představení výzkumného vzorku a výzkumného nástroje, jeho administraci a analýze získaných dat. V kapitole „Výsledky“ jsou nastíněna základní zjištění týkající se postojů studentů českých gymnázií k chemii; dále jsou zde uvedeny rozdíly ve vnímaní vyučovacího předmětu chemie mezi jednotlivými proměnnými (pohlaví, studovaný ročník a oblíbený předmět). Část „Diskuse a závěr“ uvádí odpovědi na výzkumné otázky. Je zde možné nalézt též návrh dalšího směřování výzkumu v této oblasti.

\section{TEORETICKÁ VÝCHODISKA: ZÁKLADNÍ POJMY A STAV POZNÁNÍ}

Základním zkoumaným problémem je pojem postoj, jeho složky, změna a měření. Celosvětově existuje mnoho definic tohoto pojmu, které se vzájemně odlišují v určitých znacích. Poprvé byl pojem postoj definován roku 1918, kdy Thomas a Znaniecki popsali postoje jako procesy individuálního vědomí, mající určující vliv na aktuální a budoucí reakce člověka k okolí. Mezi nejznámější a nejpoužívanější patří definice od Allporta (1967). Ten definuje postoj jako mentální a nervový stav připravenosti k reagování, který se utváří na základě zkušenosti a má usměrňující vliv na chování. Další definice vysvětluje postoje jako trvalé soustavy pozitivních nebo negativních hodnocení, emocionálního cítění a tendencí jednání pro nebo proti společenským objektům (Krech; Crutchfield; Ballachey 1968). Nakonečný (1998) definuje postoj jako „hodnotící vztah“ - mít vůči něčemu postoj znamená zaujmout vůči určitému objektu hodnotící stanovisko. Je to zvláštní prvek ve struktuře osobnosti, který vyjadřuje hodnocení objektu subjektem. Objektem hodnocení v případě vyučovacího procesu v chemii může být cokoliv - může to být chemie jako celek, případně učitelé chemie, nebo samotné hodiny výuky chemie či další aspekty související s chemií.

Před samotnou analýzou faktorů ovlivňujících postoje je důležité poukázat na to, proč je chemie (spolu s ostatními přírodovědnými předměty) pro žáky a studenty důležitá. Např́iklad Sears a Kessen (1964) uvádějí, že hlavní úlohou chemického přírodovědného vzdělávání je probudit v dítěti zájem o přírodovědné předměty a smysl

\footnotetext{
${ }^{1}$ Termín žák je používán pro dítě navštěvující základní školu, termín student pro adolescenta navštěvujícího gymnázium, střední školu nebo vysokou školu.
} 
pro radost $\mathrm{z}$ vyučování prŕrodovědných předmětů. Výrazný pokles zájmu o chemii začal celosvětově v osmdesátých letech minulého století a trvá dodnes (Koballa a Glynn, 2007). Může to být způsobeno velmi výrazným posunem v objevech v rámci chemie, které se také promítly do obsahové náročnosti předmětu a způsobily spíše přednáškové předávání znalostí před aktivním osvojováním těchto poznatků samotnými žáky a studenty. Na základě tohoto faktu vzniklo množství projektů, snažících se nalézt př́činu daného stavu. Kromě malých projektů jsou známy i velké mezinárodní studie, jako jsou PISA, TIMMS či ROSE, které se snaží najít příčinu nezájmu nejen o chemii, ale i o přírodovědné předměty obecně. Jeden z klíčových závěrů je, že pro žáky a studenty není obsah vyučovacích hodin chemie v souladu s jejich potřebami, motivací a zájmy (Sjöberg, Schreiner, 2006).

Co se týče současného stavu řešené problematiky je zřejmé, že prací, které se zaobírají zkoumáním postojů studentů gymnázií k chemii, je relativně malé množství. Jak je z uvedených prací patrné, zkoumají spíše oblíbenost vyučovacího předmětu chemie $\mathrm{v}$ rámci všech vyučovacích předmětů, než samotné postoje $\mathrm{k}$ chemii. Velmi zř́́dkavým jevem je zkoumání postojů k chemii jako vyučovacímu předmětu za pomoci škálovaných dotazníků či sémantického diferenciálu.

Z českého a slovenského prostředí je nejznámější studie od Veselského (2010), který provedl výzkum postojů studentů středních škol ke studiu přírodovědných předmětů se specifickým zaměřením na chemii (především na zájem o chemii a důležitost chemie). Výzkumný vzorek tvořili studenti prvního ročníku čtyřletého gymnázia. Hlavním zaměřením výzkumu bylo hodnocení vyučovacího předmětu, jeho obsahu a obtížnosti při studiu na základní škole (podle autora výhoda této studie spočivá v tom, že studenti mají možnost hodnotit chemii na ZŠ s určitým časovým odstupem, a v hodnocení nejsou tolik ovlivněni aktuálními zážitky z vyučování, které by mohly jejich posuzování zkreslit). Výzkumným nástrojem byl dotazník tvořený 21 položkami (ve formě 5-stupňové škály), spolu s údaji o pohlaví a sídle školy. Všeobecně mají studenti poměrně nízký zájem nejen o výuku chemie, ale o přírodovědné předměty celkově. Dívky projevují vyšší zájem než chlapci. Podle studie je zájem o chemii úzce spjat s chápáním a porozuměním učivu, možností sebeuplatnění ve výuce, používáním pomůcek a pokusů ve výuce $\mathrm{a}-\mathrm{v}$ neposlední řadě - též s osobností učitele. Höfer a Svoboda (2005) se pomocí dotazníkového šetření snažili podchytit úroveň vztahů žáků/studentů k výuce fyziky, chemie a dalších předmětů, názorů žáků/studentů na průběh vyučovací hodiny, názorů na používané učebnice i používání dalších didaktických pomůcek a také obecnější pohled žáka/studenta na výuku vůbec. Dotazník obsahoval škálované položky a byl administrován u žáků základních škol, osmiletých i čtyřletých gymnázií a středních škol. Z analýzy výsledků vyplývá výrazně špatné postavení fyziky a chemie v žebřričku oblíbenosti vyučovaných předmětů na všech uvedených typech škol. Z výzkumu také plyne velmi těsný vztah oblíbenosti předmětu s jeho obtížností, kdy autoři konstatují, že oblíbené je to, co není obtížné a naopak. Gedrovics et al. (2008) vyhodnotili postoje k chemii jako negativní a na základě položek a vypočteného skóre rozdělili respondenty do čtyř typologických skupin: na odpůrce přírodních věd, poslušné, nadšence pro přírodní vědy a na vybíravé.

Ze zahraničních studií se postoji studentů středních škol k chemii zabývali Salta a Tzougraki (2004), kteří zkoumali vliv pohlaví, studijní specializace a úspěšnosti studentů řeckých středních škol na jejich postoje $\mathrm{k}$ vyučovacímu předmětu chemie. Na zjištění postojů byl použit dotazník se škálovanými položkami. Položky v dotazníku byly rozděleny do 5 dimenzí, a to konkrétně: 1. Náročnost chemie, 2. Zájem o chemii, 3. Význam chemie, 4. Důležitost chemie pro kariéru a 5. Dů- 
ležitost chemie pro život. Autoři nevyhodnocovali celkové postoje k chemii, ale zaměřili se na vyhodnocování jednotlivých dimenzí. Kromě dimenzí „Důležitost chemie pro život" a „Důležitost chemie pro kariéru“ byl jejich postoj neutrální. Autoři zjistili negativní skóre při hodnocení „Důležitosti chemie pro kariéru“, naopak u dimenze „Důležitost chemie pro život" byly postoje studentů pozitivní. Při zkoumání vlivu pohlaví na postoje $\mathrm{k}$ chemii byl zjištěn významný rozdíl pouze v dimenzi „Náročnost chemie“, kdy dívky, v porovnání s chlapci, vnímají chemii jako náročnější. V ostatních dimenzích nebyl zjištěn statisticky významný rozdíl, ale chlapci v nich dosahovali pozitivnější postoj v porovnání s dívkami. Při zkoumání vlivu studijní kombinace dosahovali nejvyššího skóre ve všech dimenzích studenti, kteří chtěli po skončení střední školy pokračovat ve studiu medicíny. Pozitivní vztah mezi jednotlivými dimenzemi a úspěšností studentů byl detekován na základě získaných dat. Nejsilnější korelace se objevila mezi náročností chemie a úspěšností, což značí, že čím je chemie vnímána jako náročnější, tím v ní studenti dosahují horších výsledků. Kan a Akbas (2006) se zaměřili na zkoumání postojů studentů tureckých středních škol k vyučovacímu předmětu chemie. Autoři se rozhodli zjistit rozdíly mezi chlapci a dívkami, dále mezi prvním až třetím ročníkem, a také zkoumali vliv postojů $\mathrm{k}$ chemii na úspěšnost v tomto předmětu. Jako výzkumný nástroj byl použit dotazník s položkami Likertova typu. Z uvedených výsledků vyplývá pozitivnější vnímání chemie jako vyučovacího předmětu u chlapců. Z hlediska studovaného ročníku dosáhli nejpozitivnějšího stanoviska, v porovnání s ostatními skupinami, studenti navštěvující druhý ročník. Nejméně pozitivně vnímali chemii nejmladší studenti. Při vyhodnocováni vlivu postoje k chemii na úspěšnost zjistili autoři pozitivní vliv postoje, což znamená, že čím pozitivnější postoj student zaujímá, tím se dají očekávat lepší studijní výsledky. Cheung (2009) si ve své práci dal za cíl prozkoumat vliv pohlaví a navštěvovaného ročníku na postoje $\mathrm{k}$ vyučovacímu předmětu chemie u studentů středních škol z Hongkongu. Výzkumný nástroj byl ve formě škálového dotazníku, položky byly rozděleny do čtyř dimenzí (1. Hodnocení chemických vyučovacích hodin, 2. Hodnocení laboratorních cvičení, 3. Tendence k učení se chemii a 4. Hodnocení chemie studenty z hlediska její náročnosti a významu). Autor ve své studii nevyhodnocoval postoje $\mathrm{k}$ chemii jako celku, ale vyhodnocoval jednotlivé dimenze. Významný efekt byl zjištěn zejména u prvních dvou dimenzí, a to pozitivnější hodnocení u chlapců v porovnání s děvčaty. Autor na závěr konstatuje pozitivní vnímání chemie u chlapců i u dívek.

\section{DŮVOD VÝZKUMNÉHo ŠETŘENí}

Jak je nastíněno výše, dostupných výzkumných prací, týkajících se zjištování postojů studentů gymnázií k chemii, není mnoho. Proto je jedním z důvodů výzkumného šetření rozššřit výzkumnou oblast, týkající se zkoumání postojů českých studentů gymnázií se všeobecným zaměřením $\mathrm{k}$ chemii. Kromě zjištění, jaká je úroveň postojů k chemii, byl zjištován také vliv pohlaví, ročníku a oblíbeného předmětu na postoje studentů k chemii. Tyto faktory byly vybrány v důsledku možnosti porovnání studie s dalšími výzkumnými šetřeními, v nichž byl použit podobný výzkumný nástroj a stejné proměnné. Nabízí se také možnost výzkumu, který je založený na sledování ovlivnění postojů studentů k vyučovacímu předmětu chemie osobností učitele, osvojovaným učivem, metodami výuky a dalšími, což by však překračovalo navrhovaný rámec předkládané studie. 
Byly stanoveny následující výzkumné otázky:

1. Jaký je vliv pohlaví na úroveň postojů studentů $\mathrm{k}$ chemii?

2. Existuje vztah mezi ročníky, které studenti navštěvují, a úrovní postojů k chemii?

3. Existuje vztah mezi oblíbeným předmětem a postojem $\mathrm{k}$ chemii?

Na základě výzkumných otázek byly formulovány následující hypotézy:

H1: Chlapci mají pozitivnější postoje $\mathrm{k}$ chemii v porovnání s dívkami.

H2: S rostoucím ročníkem jsou postoje studentů gymnázií $\mathrm{k}$ chemii pozitivnější.

H3: Studenti s oblíbeným přírodovědným předmětem mají pozitivnější postoje k chemii, než studenti s jiným oblíbeným předmětem.

\section{Metodika}

\subsection{VÝZKUMNÝ VZOREK}

Výzkumný vzorek byl tvořen 552 studenty ze čtyř českých gymnázií se všeobecným zaměřením. Gymnázia byla vybrána náhodně. Děvčata tvořila $64,13 \%$ výzkumného vzorku ( $n=354$ - viz tabulka 1$)$. Do výzkumného šetření byli zahrnuti studenti prvních až třetích ročníků všeobecných gymnázií. Studenti čtvrtého ročníku nebyli do analýz zahrnuti, nebot chemie není na českých gymnáziích ve čtvrtém ročníku vyučována - studenti své znalosti z tohoto oboru rozšiřují ve volitelném předmětu biologicko-chemický seminár̆, a proto předpokládáme jak pozitivní postoj k chemii, tak vyšší znalosti a dovednosti v oblasti chemie. Průměrný věk respondentů byl $16,71(S D=1,04)$ a pohyboval se v rozmezí od 15 do 19 let. Podle oblíbeného předmětu byli studenti rozděleni do dvou skupin: první tvořili studenti, kteř́ jako svůj oblíbený předmět označili předmět př́rodovědně zaměřený $(n=187)$, druhá část byla tvořena studenty s oblíbeným předmětem jiným, než přírodovědným $(n=393)$. Mezi př́rodovědné předměty byly zařazeny biologie, chemie, fyzika a zeměpis.

Tab. 1: Základní demografické údaje výzkumného vzorku

\begin{tabular}{|c|c|c|c|c|c|c|c|c|}
\hline \multirow{2}{*}{$\begin{array}{l}\text { Počet } \\
\text { respondentů }\end{array}$} & \multirow[b]{2}{*}{ Chlapci } & \multirow{2}{*}{ Dívky } & \multicolumn{3}{|c|}{ Ročník } & \multicolumn{2}{|c|}{ Oblíbený předmět } & \multirow{2}{*}{$\begin{array}{l}\text { Průměrný } \\
\text { věk }\end{array}$} \\
\hline & & & 1. & 2. & 3. & př́rodovědný & nepřírodovědný & \\
\hline 552 & 198 & 354 & 145 & 113 & $\overline{294}$ & 187 & 393 & $\begin{array}{c}16,71 \\
(S D=1,04)\end{array}$ \\
\hline
\end{tabular}

\subsection{VÝZKUMNÝ NÁSTROJ}

Výzkumným nástrojem byl dotazník Likertova typu, obsahující 25 škálovaných položek. Podkladem pro tvorbu výzkumného nástroje byl dotazník použitý na měření postojů žáků základní školy k přírodopisu (Prokop, Komorníková, 2007), který byl po záměně pojmu př́rodopis za chemii použit na měření postojů žáků druhého stupně základních škol k vyučovacímu předmětu chemie (Kubiatko et al., 2012).

Dotazník byl rozdělen na dvě části: první byla tvořena 25 postojovými položkami, druhou tvořily demografické položky (pohlaví, věk, ročník, oblíbený předmět). Na základě faktorové analýzy byly položky rozděleny do čtyř kategorií: 1. Významnost chemie, 2. Oblíbenost a náročnost chemie, 3. Chemické pomůcky a laboratorní experimenty a 4. Zájem o chemii (viz podkapitola 4.4 Analýza získaných dat). Postojové položky byly uvedeny jak v pozitivním významu, tak i v negativním významu. Celkový počet pozitivních položek byl 15. Ty byly pro další možnosti statistického 
zpracování překódovány následovně: zcela nesouhlasím - 1 ; spíše nesouhlasím -2 ; nevím - 3; spíše souhlasím - 4; zcela souhlasím - 5 . Negativní položky byly překódovány v opačném pořadí. Celkové skóre ukázalo postoje studentů k chemii - nízké skóre reflektovalo relativně negativní postoj studentů k chemii, vysoké skóre postoj relativně pozitivní, přičemž jako neutrální postoj je chápáno celkové skóre v rozmezí od 2,75 po 3,25 . Validita výzkumného nástroje byla zabezpečena dvěma způsoby, které se vztahovaly ke konstruktové validitě. V prvním případě byla určena odborníkem na tvorbu dotazníků a také učitelem z praxe. Hodnotitelé byli požádáni, aby se vyjádřili k jednotlivým položkám, jejich srozumitelnosti a náročnosti. Všechny položky vyšly jako srozumitelné a jejich náročnost byla odpovídající stupni vzdělání studentů. Druhým způsobem určení konstruktové validity byla realizace explorativní faktorové analýzy (viz podkapitola 4.4 Analýza získaných dat).

\subsection{Administrace VÝZKUMNÉHO NÁSTROJE}

Výzkumný nástroj byl administrován na čtyřech českých gymnáziích se všeobecným zaměřením. Školy byly městského typu, kde počet studentů v žádné ze tříd nepřesáhl 30. Ve všech případech byli administrátory učitelé chemie, kteří byli poučeni, jak pracovat s výzkumným nástrojem, aby mohli zodpovědět případné otázky studentů. Studenti byli obeznámeni s anonymitou výzkumného nástroje, a také s tím, že získané údaje budou použity pouze pro výzkumné účely. Respondentům nebyl zadán časový limit pro vyplnění, doba vypracování nepřesáhla 20 minut.

\subsection{ANALÝZA ZÍSKANÝCH DAT}

Získané údaje byly po jejich převedení do číselné podoby podrobeny explorativní faktorové analýze s Varimax rotací s vlastním číslem větším než 1,00. Před samotným použitím faktorové analýzy bylo nutné provést testy, které dovolují její použití, konkrétně Kaiser-Meyer-Olkinův test (KMO) a Bartlettův teste sféricity. Hodnota KMO testu byla 0,91, hodnota Bartlettova testu $\left(\chi^{2}=5113,99 ; p<0,001\right)$. Uvedené hodnoty obou testů indikují použití explorativní faktorové analýzy. Na základě faktorové analýzy byly položky výzkumného nástroje rozděleny do čtyř kategorií (viz tabulka 2). První kategorií je Významnost chemie (4 položky), druhou tvoří Oblíbenost a náročnost chemie (4 položky), dále Chemické pomůcky a laboratorní experimenty ( 8 položek) a Zájem o chemii (4 položky). Tyto kategorie vysvětlovaly 49,82 \% celkového rozptylu. Nejvíce bylo vysvětleno kategorií 1 (28,53\%). Z celkového počtu 25 položek jich bylo 5 vyřazeno, nebot hodnota faktorového skóre u nich byla nižší než 0,40 .

Reliabilita výzkumného nástroje byla stanovena pomocí Cronbachovo alfa koeficientu, jehož hodnota $(\alpha=0,86)$ indikuje vysokou spolehlivost výzkumného nástroje. Na zjištování statisticky významných rozdílů mezi skupinami nezávisle proměnných byly použity testy induktivní statistiky. Použití Kolmogorova-Smirnovova testu potvrdilo normální rozložení dat $(d=0,05 ; p>0,50)$, což umožnilo použít parametrické statistické metody zpracování dat. Konkrétně pro výpočet byla použita analýza rozptylu (ANOVA), ve které bylo skóre z postojové části výzkumného nástroje bráno jako závisle proměnná a demografické položky byly brány jako nezávisle proměnné. $\mathrm{V}$ př́padě výskytu více než dvou skupin u nezávisle proměnné byl na detailnější stanovení rozdílů použit Tukeyho post-hoc test. Na výpočet byly použity programy Microsoft Office Excel a Statistica 10.0. 
Tab. 2: Výsledky explorativní faktorové analýzy

\begin{tabular}{|c|c|c|c|c|c|}
\hline & $\alpha$ & I. & II. & III. & IV. \\
\hline (I) Významnost chemie & 0,66 & & & & \\
\hline 9. Pokrok v oblasti chemie zkvalitňuje naše životy. & & 0,73 & 0,07 & 0,07 & $-0,09$ \\
\hline $\begin{array}{l}\text { 11. Chemické poznatky mohou pomoci při řešení } \\
\text { problémů souvisejících s př́rodním prostředím. }\end{array}$ & & $\overline{0,73}$ & 0,07 & 0,08 & 0,03 \\
\hline $\begin{array}{l}\text { 23. Procesy probíhající v přírodě považuji za } \\
\text { zajímavé. }\end{array}$ & & 0,64 & 0,09 & 0,13 & 0,26 \\
\hline 24. Chemické experimenty jsou velmi zajímavé. & & 0,46 & 0,01 & 0,46 & 0,26 \\
\hline (II) Oblíbenost a náročnost chemie & 0,79 & & & & \\
\hline 1. Chemii mám raději než ostatní předměty. & & 0,08 & 0,53 & 0,38 & 0,38 \\
\hline 4. Hodiny chemie jsou pro mě náročné. & & 0,11 & $\mathbf{0 , 7 7}$ & 0,27 & 0,07 \\
\hline $\begin{array}{l}\text { 16. Abych porozuměl/a chemickému učivu, musím se } \\
\text { více soustředit. }\end{array}$ & & 0,02 & 0,80 & $-0,08$ & 0,01 \\
\hline $\begin{array}{l}\text { 25. Domnívám se, že chemie je jeden z nejlehčích } \\
\text { vyučovacích předmětů. }\end{array}$ & & 0,06 & 0,78 & 0,12 & 0,14 \\
\hline $\begin{array}{l}\text { (III) Chemické pomůcky a laboratorní } \\
\text { experimenty }\end{array}$ & 0,78 & & & & \\
\hline 2. Na hodinách chemie nepoužíváme žádné pomůcky. & & $-0,05$ & $-0,09$ & 0,66 & $-0,07$ \\
\hline $\begin{array}{l}\text { 5. Při chemických laboratorních cvičeních dochází } \\
\text { k rozvoji mých vědomostí a dovedností. }\end{array}$ & & 0,34 & 0,08 & 0,55 & 0,21 \\
\hline 8. V hodinách chemie se nudím. & & 0,06 & 0,10 & 0,76 & 0,09 \\
\hline $\begin{array}{l}\text { 10. Výklad učitele v hodinách chemie je pro mě } \\
\text { zajímavý. }\end{array}$ & & 0,13 & 0,14 & 0,78 & $-0,03$ \\
\hline $\begin{array}{l}\text { 14. Chemické pomůcky využívané v hodinách chemie } \\
\text { mě zajímají. }\end{array}$ & & 0,39 & 0,02 & 0,41 & 0,29 \\
\hline $\begin{array}{l}\text { 15. Domnívám se, že ve srovnání s ostatními } \\
\text { vyučovacími předměty není chemie důležitá. }\end{array}$ & & 0,22 & 0,34 & 0,42 & 0,40 \\
\hline 20. Nemám rád/a hodiny chemie. & & 0,15 & 0,38 & $\mathbf{0 , 6 2}$ & 0,28 \\
\hline $\begin{array}{l}\text { 22. V hodinách chemie používáme hodně chemických } \\
\text { pomůcek. }\end{array}$ & & 0,03 & 0,24 & 0,55 & $-0,09$ \\
\hline (IV) Zájem o chemii & 0,51 & & & & \\
\hline 6. Hodiny chemie bych chtěl/a mít častěji. & & 0,10 & 0,06 & 0,07 & 0,63 \\
\hline $\begin{array}{l}\text { 13. Moje budoucí kariéra je nezávislá od vědomostí } \\
\text { z chemie. }\end{array}$ & & 0,00 & 0,13 & 0,08 & 0,78 \\
\hline $\begin{array}{l}\text { 18. Po dokončení studia bych chtěl/a pracovat } \\
\text { v oblasti přírodních věd. }\end{array}$ & & 0,21 & 0,19 & 0,23 & 0,69 \\
\hline $\begin{array}{l}\text { 19. Poznatky z chemie nejsou pro každodenní život } \\
\text { potřebné. }\end{array}$ & & 0,24 & 0,26 & 0,15 & 0,46 \\
\hline vlastní číslo & & 7,13 & 2,08 & 1,92 & 1,32 \\
\hline rozptyl (\%) & & 28,53 & 8,31 & 7,67 & 5,30 \\
\hline Vyřazené položky & & & & & \\
\hline 3. Chemie a příroda jsou mi cizí. & & 0,06 & $-0,10$ & $-0,11$ & 0,39 \\
\hline $\begin{array}{l}\text { 7. Vědomosti z chemie jsou důležité pro porozumění } \\
\text { jiným vyučovacím předmětům. }\end{array}$ & & $-0,04$ & 0,07 & 0,14 & 0,34 \\
\hline $\begin{array}{l}\text { 12. Chemie mě zajímá pouze kvůli našemu učiteli } \\
\text { chemie. }\end{array}$ & & $\overline{-0,24}$ & $-0,09$ & 0,35 & $-0,14$ \\
\hline 17. Příroda je důležitou součástí lidského života. & & 0,35 & $-0,05$ & 0,16 & $-0,01$ \\
\hline 21. Nemám rád/a mého učitele/učitelku chemie. & & 0,09 & 0,10 & 0,18 & $-0,11$ \\
\hline
\end{tabular}

$\alpha$ - Cronbachovo alfa

Čísla položek jsou identická s čísly položek ve výzkumném nástroji. 


\section{VÝSLEDKY}

Celkové skóre postojové části dotazníku bylo $3,21(S D=0,63)$, což indikovalo neutrální postoj studentů k vyučovacímu předmětu chemie. Při detailnějším pohledu na graf 1 je patrné, že studenti vidí význam chemie, a též relativně pozitivně vnímají využívání chemických pomůcek a laboratorních experimentů; zájem o chemii je neutrální. Jedinou negativní položkou je oblíbenost a náročnost chemie, kdy podle studentů je chemie spíše neoblíbená, a to zejména pro svoji náročnost a množství poznatki̊, které je potřeba si osvojit v poměrně krátkém čase.

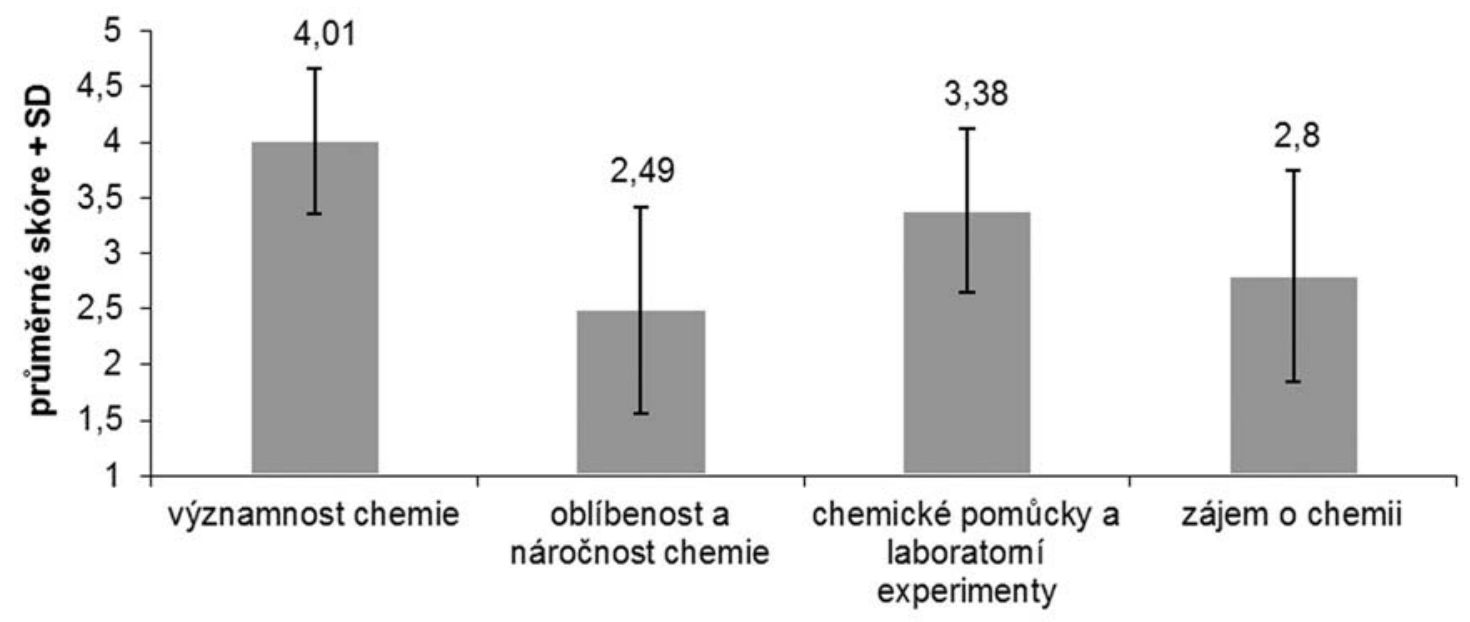

kategorie

Graf 1: Průměrné skóre jednotlivých kategorií

\subsection{VLIV OBLÍBENÉHO PŘEDMĚTU NA POSTOJE K CHEMII}

Vliv oblíbeného předmětu se ukázal jako významný faktor ovlivňující postoje studentů $\mathrm{k}$ chemii $(F=96,98 ; p<0,001)$, kdy studenti s oblíbeným př́rodovědným předmětem mají mnohem pozitivnější postoj (průměrné skóre $x=3,54, S D=0,04$ ) než studenti, kteří označili za svůj oblíbený předmět jiný, než je př́rodovědný, a jejichž postoj je neutrální $(x=3,06, S D=0,03)$ (graf 2). Z položkové analýzy vyplývá, že studenti s oblíbeným přírodovědným předmětem mají pozitivní vztah $\mathrm{k}$ chemii, rádi by měli více hodin chemie a velký přínos vidí v pochopení procesů, které probíhají v přírodě z chemického hlediska. Obě zkoumané skupiny se neliší ve vztahu k náročnosti chemie a též je shodné jejich pozitivní stanovisko ke zkvalitňování našeho života za využití nových poznatků z chemie. Studenti s oblíbeným jiným než přírodovědným předmětem nevidí takovou významnost chemie, a také hodiny chemie spíše nemají rádi; často uvádějí, že se na těchto hodinách nudí. Hypotéza o vlivu oblíbeného předmětu se akceptuje na hladině významnosti $p<0,001$, protože studenti s oblíbeným př́rodovědným předmětem zaujímali v porovnání se studenty, kteří mají oblíbený předmět jiný než prrírodovědný, pozitivnější postoj k tomuto předmětu.

\subsection{Vliv POHLAVÍ NA POSTOJE K CHEMII}

Graf 3 znázorňuje vliv pohlaví na postoje studentů $\mathrm{k}$ chemii. Ten nebyl statisticky významný $(F=1,43 ; p=0,23)$. Při detailnějším pohledu lze pozorovat, že mezi 


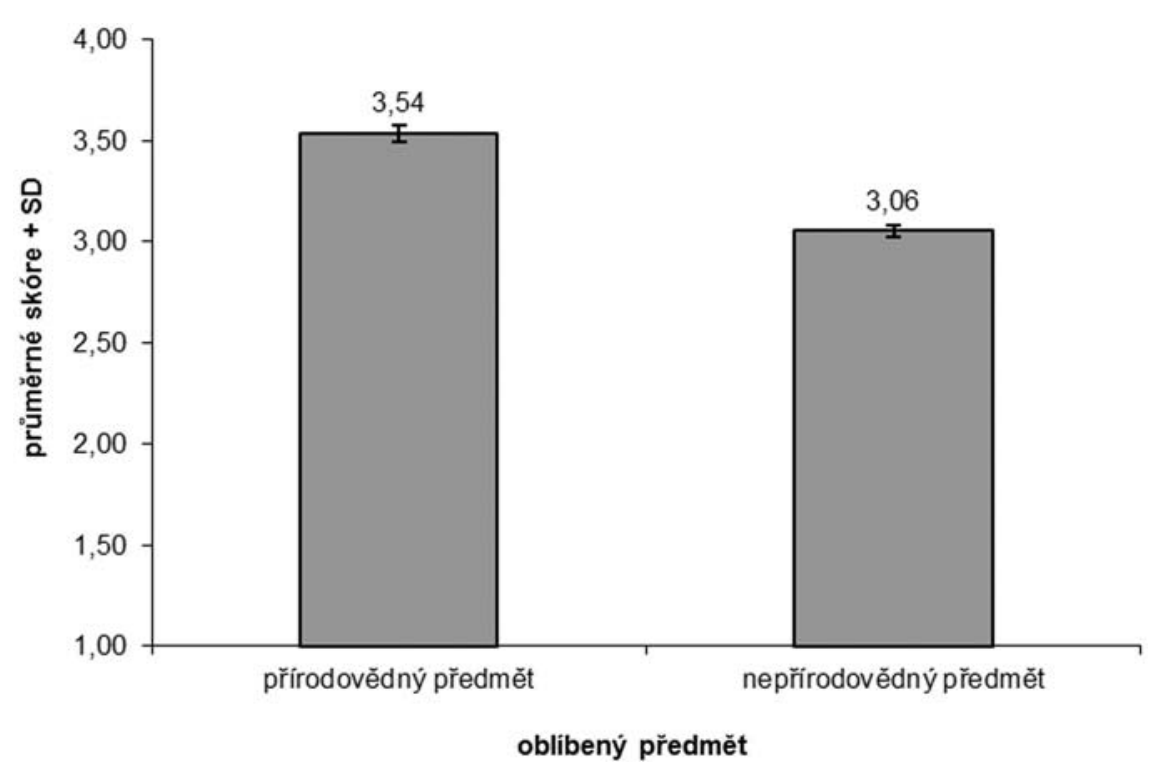

Graf 2: Postoje k chemii podle oblíbeného předmětu

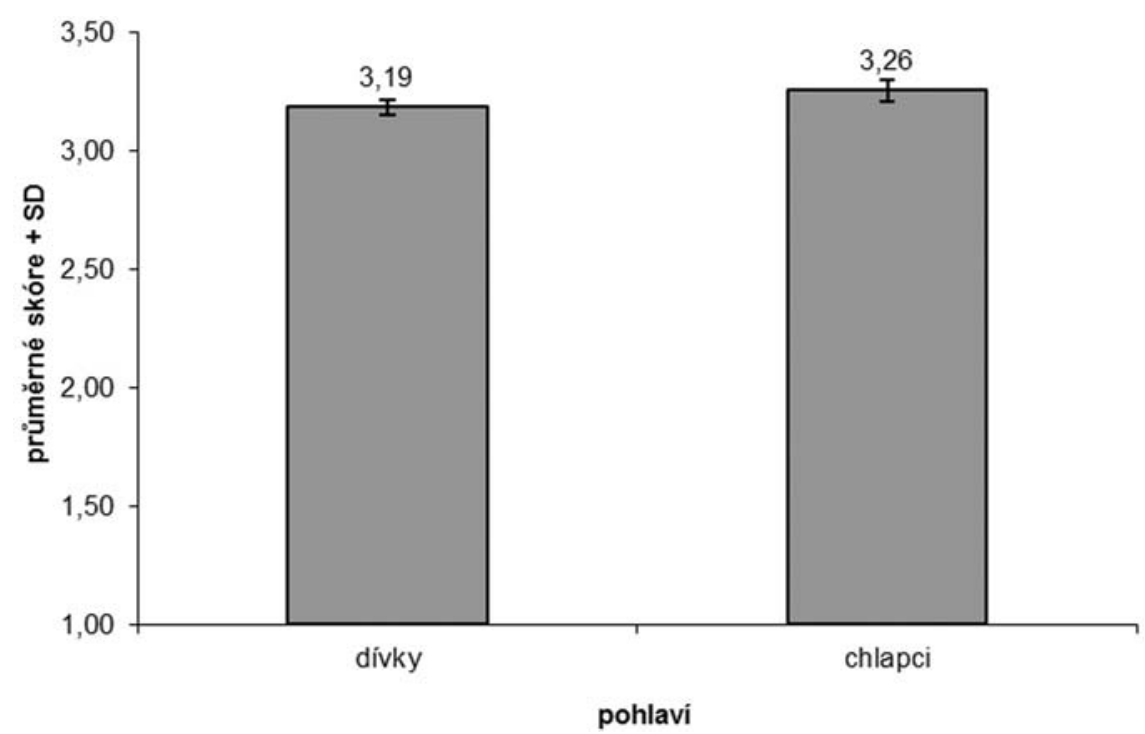

Graf 3: Postoje k chemii podle pohlaví

chlapci a dívkami byl rozdíl ve skóre ve prospěch chlapců $(x=3,26 ; S D=0,04)$ v porovnání s dívkami $(x=3,19 ; S D=0,03)$. Na základě uvedeného zjištění je možné konstatovat přibližně podobný zájem o chemii, také obě skupiny vidí přibližně stejný význam chemie, ale dívky - v porovnání s chlapci - vidí hodiny chemie jako náročnější, což může být způsobeno jiným přístupem k učení. Chemie je abstraktní předmět, který vyžaduje vysokou úroveň abstraktního myšlení. To je všeobecně rozvinutější u chlapců nežli u dívek, které přri řešení úloh využívají především naučené definice a lépe si zapamatují a pochopí věci a jevy, jež dokážou samy pozorovat. Daný fakt je možné potvrdit i analýzou položek spadajících do kategorie oblíbenosti a náročnosti, zejména se jedná o položku, která zjištovala, zdali se studenti musí více soustředit, aby pochopili chemické učivo. Při uvedené položce byl zjištěn rozdíl, kdy dívky musí vynaložit více energie na pochopení chemického učiva než chlapci (alespoň dle jejich odpovědí). Také v další položce zařazené do uvedené kategorie považovalo více chlapců chemii za jeden z nejlehčích předmětů, což je ve spojitosti s náročností učiva v ní obsaženého. Jak chlapci, tak i dívky mají neutrální vztah 
$\mathrm{k}$ důležitosti chemie, tu však velmi zřetelně vidí především ve zkvalitňování lidského života na základě nových chemických poznatků.

\subsection{VLIV ROČNÍKU NA POSTOJE K CHEMII}

Výsledky týkající se postojů k chemii na základě navštěvovaného ročníku ukázaly statisticky významný rozdíl $(F=9,54 ; p<0,001)$. Hodnota skóre u studentů prvního ročníku byla $3,37(S D=0,05)$, studenti druhého ročníku dosáhli celkového skóre 3,22 $(S D=0,06)$ a celkové skóre studentů třetího ročníku je 3,09 $(S D=0,03)$. Použitím Tukey post-hoc testu bylo zjištěno, že významný rozdíl je pouze mezi studenty třetího a prvního ročníku $(p<0,001)$, kdy studenti prvního ročníku mají k chemii pozitivní postoj, zatímco studenti ročníku třetího mají postoj neutrální (graf 4). Jednou z možností, proč dochází u studentů ke změně úrovně postojů směrem k negativnímu vnímání chemie, je i obsah učiva $\mathrm{v}$ jednotlivých ročnících. Pravděpodobně většina učitelů směruje do prvního ročníku učivo týkající se obecné chemie a anorganické chemie, která může být pro studenty zajímavější, a proto je i jejich hodnocení chemie pozitivnější. Svědčí o tom i fakt, že spolu se stoupajícím ročníkem označovalo více studentů možnost, že se na hodinách chemie nudí. Zatímco u studentů prvního ročníku to bylo nízké číslo, tak u studentů druhého a třetího ročníků počet nudících se na hodinách chemie prudce stoupal. Také to potvrzuje položka týkající se zhodnocení náročnosti vyučovacího předmětu chemie. Jako náročnější označovali tento předmět studenti druhého a třetího ročníku. Studentů, kteří označili chemii za náročnou, bylo v porovnání s jejich staršími kolegy méně.

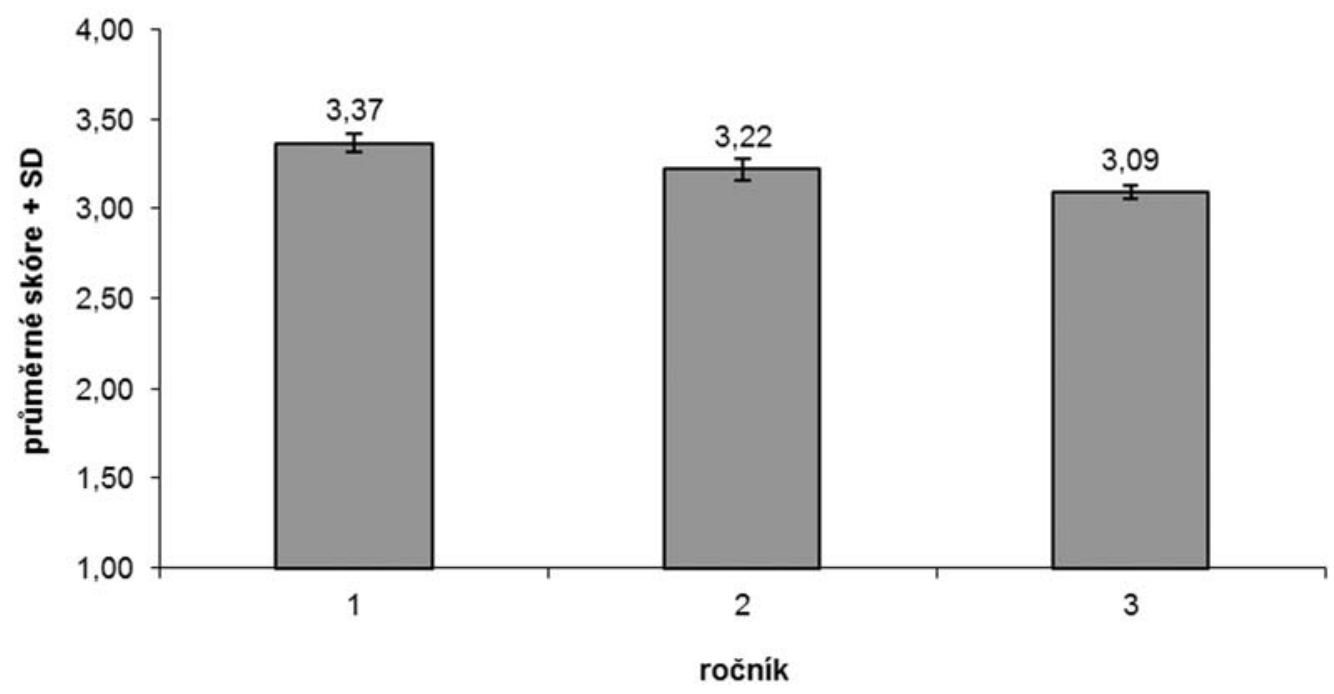

Graf 4: Postoje k chemii podle navštěvovaného ročníku

\section{Diskuse A ZÁVĚR}

Cílem prezentovaného výzkumného šetření bylo zjistit postoj studentů českých gymnázií $\mathrm{k}$ vyučovacímu předmětu chemie. Doplňkovým cílem bylo zjistit, jaký vliv na utváření postojů mají pohlaví, studovaný ročník a oblíbený předmět. Jako výzkumný nástroj byl použit dotazník s 5-stupňovými škálovanými položkami, který lze po určitých úpravách použít i na zkoumání postojů k jiným předmětům, než je chemie, přičemž se nemusí jednat pouze o přírodovědné předměty (biologie, fyzika, zeměpis). Výzkumný nástroj lze použít i na zkoumání jiné věkové skupiny respondenti̊, např́klad na vysokých školách. Záměrem autorů bylo také přsispět k nevelkému počtu 
výzkumných prací, které by se zabývaly obdobným tématem. Celkově byl zjištěn neutrální postoj studentů k chemii, což může být způsobeno obsahem vyučovacím předmětu. Tematické celky se probírají v rychlém sledu za sebou a jejich obsahová náplň je různorodá. Proto kvůli krátkému časovému působení nemusí dojít k pozitivnímu či negativnímu vyhranění k uvedenému předmětu.

První stanovená hypotéza „Chlapci mají pozitivnější postoje k chemii v porovnání s dívkami“ se zamítá, protože nebyl zjištěn statisticky významný rozdíl v postojích k chemii ve prospěch chlapců. Přestože hypotéza byla zamítnuta, chlapci dosáhli vyššího skóre než děvčata. Podobných výsledků dosáhli Barnes et al. (2005), Cheung (2009), Kan a Akbas (2006) a Ozden (2008), kteří zjistili pozitivnější vnímání chemie u chlapců než u dívek. Opačného výsledku, tedy pozitivnějšího vnímání chemie děvčaty, dosáhli ve své práci Hofstein et al. (1977). Jak je možné vidět nejen z předloženého výzkumného šetření, ale též ze šetření jiných, v současné době se ukazuje trend pozitivnějšího vnímání chemie u chlapců v porovnání s dívkami. Zjištění je podpořeno i faktem, který ve své studii uvádí Ramsden (1998). Ten proklamuje pozitivnější vnímání př́rodovědných předmětů (mezi které je řazena i chemie) u chlapců. Druhá hypotéza si kladla za úkol potvrdit nebo vyvrátit tvrzení, že s rostoucím ročníkem jsou postoje studentů k vyučovacímu předmětu chemie pozitivnější. Analýzou rozptylu byl zjištěn statisticky významný rozdíl, a to především mezi studenty prvního a třetího ročníku. Zatímco studenti prvního ročníku mají k chemii pozitivní postoj, u studentů druhého a třetího ročníku je postoj již neutrální. Celkově je možné říci, že s narůstajícím věkem studentů klesá zájem o vyučovací předmět chemie. Změnu postojů $\mathrm{k}$ chemii s rostoucím ročníkem studia zaznamenali ve svých studiích též Hilbink a Barke (2000), Hofstein et al. (1977) a Kan a Akbas (2006). Menis (1989), zkoumající postoje amerických žáků k chemii, zjistil opačný trend, tedy že starší žáci měli pozitivnější postoje k chemii, mladší negativnější. Pokud pomineme studenty čtvrtého ročníku, ovlivněné oblíbeností přírodovědných předmětů, můžeme hypotézu číslo dvě zamítnout, nebot u starších studentů je výrazný pokles zájmu o chemii spojený s poklesem postojů $\mathrm{k}$ tomuto předmětu. Vzhledem $\mathrm{k}$ tomu, že výzkum nebyl prováděn longitudinálně, mohl každý ročník učit jiný učitel, a tím pádem mít jiný vliv na studenty, a tím ovlivňovat i jejich úroveň postojů $\mathrm{k}$ danému předmětu. Druhou možností, proč dochází k poklesu zájmu studentů o vyučovací předmět chemie, je změna zájmů studentů. Po přechodu ze základní školy na gymnázium mohli být studenti ještě plní ideálů a očekávání a projevovali zájem o školní předměty. V následujících ročnících již byli ovlivněni spolužáky a do centra jejich zájmů se dostávaly jiné aspekty, které vytlačovaly zájem nejen o chemii, ale také i fakt, že studenti se profilují a do centra jejich zájmů se dostávají i jiné předměty, na které se chtějí vázat při dalším studiu. Proto chemii posouvají do pozadí. Poslední (třetí) hypotézu, konstatující, že studenti s oblíbeným předmětem chemie (nebo jiným př́rodovědným předmětem) mají pozitivnější postoje $\mathrm{k}$ danému předmětu než studenti s jiným oblíbeným než přírodovědným předmětem, můžeme na základě získaných údajů potvrdit. Vliv oblíbeného předmětu se ukázal jako významný faktor ovlivňující postoje studentů k chemii, kdy studenti s oblíbeným přírodovědným předmětem mají mnohem pozitivnější postoj než studenti, kteří označili za svůj oblíbený předmět jiný, než je přírodovědný (jejichž postoj je neutrální). Podobných výsledků dosáhli i Ozden (2008) a Salta a Tzougraki (2004). Sledování této proměnné není ve výzkumných pracích častým jevem. Dá se s jistotou předpokládat, že studenti s oblíbeným předmětem chemie, či jiným přírodovědným předmětem, budou chemii hodnotit o mnoho pozitivněji než studenti s jiným oblíbeným než přírodovědným předmětem. Při hodnocení vlivu uvedené proměnné (oblíbený předmět) nejde pouze 
o potvrzení jejího vlivu na úroveň postojů, ale také o potvrzení reliability výzkumného nástroje.

Jak ukazují získané výsledky, tak i výsledky některých starších studií (Höfer, Svoboda, 2005; Pavelková, Škaloudová, Hrabal, 2010; Veselský, Hrubišková, 2009), patří chemie spíše mezi neoblíbené předměty. Jak však bylo zjištěno, zájem o chemii a oblíbenost chemie rostou spolu s využíváním chemických pomůcek a laboratorních experimentů ve výuce. Vliv chemických experimentů na pozitivní utváření postojů potvrzuje i studie od autorů Wolfa a Frasera (2008). Bohužel na základě nedostatečného (nebo často i nevhodného) materiálního zabezpečení není těchto možností většinou adekvátně využíváno. Pokud bude ve výuce chemie vyučující předvádět alespoň demonstrační pokusy (které nejsou tak časově a materiálně náročné), může získat větší pozornost studentů a tím ovlivnit jejich postoj $\mathrm{k}$ danému předmětu (původně neutrální postoj se začne měnit v postoj pozitivní). Taktéž přiblížení poznatků z chemie každodennímu životu (propojení s praxí, nap̌r. metody oddělování směsí a výroba ethanolu, zpracování kovů na předměty denní potřeby, redoxní děje a autobaterie, deriváty organických sloučenin a jejich využití v běžném životě, léčiva a drogy - tedy témata, o které studenti jeví zájem, nebot se s nimi ve svém věku často setkávají) pozitivně ovlivňuje vnímání chemie. Další z možností je též aplikovat do výuky chemie i metody neformálního vzdělávání, prvky kooperativního a problémového vyučování, během nichž se studenti učí vědeckým postupům, pozorování jevů, analyzování a plánování různých experimentů. Aplikaci neformálního vzdělávání podporuje i Salmi (2003), podle kterého má neformální vzdělávání vliv na zvýšení vnitřní motivace $\mathrm{k}$ přírodovědným předmětům. Výzkum v této oblasti by se mohl dále ubírat zjištěním vlivu dalších faktorů, jako je například osobnost učitele či probírané učivo.

\section{LITERATURA}

ALLPORT, G. W. Attitudes. In Fishbein, M. (Ed.)Readings in attitude theory and measurement. New York : J. Wiley, 1967, s. 3-13.

BARNES, G., MCINERNEY, D. M., MARSH, H. W. Exploring sex differences in science enrolmentintentions: An application of the general model of academic choice. Australian Educational Researcher. 2005, roč. 32, č. 2, s. 1-23.

CHEUNG, D. Students' attitudes toward chemistry lessons: The interaction effect between grade level and gender. Research in Science Education. 2009, roč. 39, č. 1, s. $75-91$.

GEDROVICS, J., BÍLEK, M., JANIUK, R. M., MOJSA, R., MOZHEIKA, D., ŘÁDKOVÁ, O. Trendy v zájmech a postojích patnáctiletých žáků k př́rodním vědám. Acta Facultatis Paedagogicae Universitatis Tyrnaviensis, 2008. Série B, 12, s. 13-17.

HILBING, C., BARKE, H. D. An idea of science: Attitudes towards chemistry and chemical education expressed by artistic paintings. Chemistry Education: Research and Practice in Europe, 2000, roč. 1, č. 3, s. 365-374.

HÖFER, G., SVOBODA, E. Některé výsledky celostátního výzkumu „Vztah žáků ZS̆ a SS̆ k výuce obecně a zvláště pak k výuce fyziky“. In Rauner, K. (ed.): Moderní trendy v př́pravě učitelů fyziky 2, Rámcové vzdělávací programy. Sborník z konference. Plzeň : Západočeská univerzita, 2005, s. 52-70. 
HOFSTEIN, A., BEN-ZVI, R., SAMUEL, D., TAMIR, P. Attitudes of Israeli highschool students toward chemistry and physics: A comparative study. Science Education. 1977 , roč. 6 , č. 2 , s. 259-268.

KAN, A., AKBAS, A. Affective Factors That Influence Chemistry Achievement (Attitude and Self Efficacy) and The Power Of These Factors To Predict Chemistry Achievement-I. Journal of Turkish Science Education. 2006, roč. 3, č. 1, s. 76-85.

KOBALLA, T. R., GLYNN, S. M. Attitudinal and motivational constructs in science learning. In Abell, S. K. and Lederman, N. G. (ed.) Handbook of Research on Science Education. Mahwah : Lawrence Erlbaum Associates, 2007, s. 75-102.

KRECH, D., CRUTCHFIELD, R. S., BALLACHEY, E. L. Člověk v společnosti. Bratislava : SAV, 1968.

KUBIATKO, M., ŠVANDOVÁ, K., ŠIBOR, J., ŠKODA, J. Vnímání chemie žáky druhého stupně základních škol. Pedagogická orientace. 2012, roč. 22, č. 1, s. 82-96.

MENIS, J. Attitudes towards School, Chemistry and Science among Upper Secondary Chemistry Students in the United States. Research in Science $\&$ Technological Education. 1989, roč. 7, č. 2, s. 183-190.

NAKONEČNY, M. Psychologie osobnosti. Vyd. 2. Praha : Academia, 1998, 333 s.

OZDEN, M. An Investigation of Some Factors Affecting Attitudes toward Chemistry in University Education. Essays in Education, Special Edition, 2008, s. 90-99.

PAVELKOVÁ, I., ŠKALOUdOVÁ, A., HRABAL, V. Analýza vyučovacích předmětů na základě výpovědí žáků. Pedagogika. 2010, roč. 55, č. 1, s. 38-61.

PROKOP, P., KOMORNÍKOVÁ, M. Postoje k prírodopisu u žiakov druhého stupňa základných škôl. Pedagogika. 2007, roč. 57, č. 1, s. 37-46.

RAMSDEN, J. M. Mission impossible? Can anything be done about attitudes to science? International Journal of Science Education. 1998, roč. 20, č. 2, s. 125-137.

SALMI, H. Science centers as leasing laboratories: Experience of Heureka, the Finnish Science Centre. International Journal of Technology Management. 2003, roč. 25, č. 5 , s. $460-476$.

SALTA, K., TZOUGRAKI, Ch. Attitudes toward chemistry among 11th grade students in high schools in Greece. Science Education. 2004, roč. 88, č. 4, s. 535-547.

SEARS, P. B., KESSEN, W. Statement of purposes and objectives of science education in school. Journal of Research in Science Teaching. 1964, roč. 2, č. 1, s. 3-6.

SJÖBERG, S., SCHREINER, C. Science education and youthd's identity construction - two incompatible projects? In Corrigan, D., Dillon, J. and Gunstone, R. (ed.): The Re-emergence of Values in the Science Curriculum. Rotterdam : Sense Publishers. 2006 [online] [cit. 12. 2. 2012]. Dostupné z: 〈http://folk.uio.no/sveinsj/ValuesROSE-Schreiner-Sjoberg.pdf $\rangle$

THOMAS, W. I., ZNANIECKY, F. Polish peasant in Europe and America. Boston : Badger, 1918 sv. 1.

VESELSKÝ, M. Motivácia žiakov učit’ sa. Bratislava : Univerzita Komenského, 2010, 116 s. ISBN 978-80-223-2820-3.

VESELSKÝ, M., HRUBIŠKOVÁ, H. Zájem žáků o učební předmět chemie. Pedagogická orientace. 2009 , roč. 19 , č. 3, s. 45-64. 
WOLF, S. J., FRASER, B. J. Learning environment, attitudes and achievement among middle-school science students using inquiry-based laboratory activities. Research in Science Education. 2008, roč. 38, č. 3, s. 321-341.

PhDr. Kateřina Švandová - E-mail: katkasvandova@gmail.com

Katedra biologie, Pedagogická fakulta MU

Poříčí 7, 60300 Brno

PaedDr. Milan Kubiatko, Ph.D. - E-mail: mkubiatko@gmail.com

Institut výzkumu školního vzdělávání, Pedagogická fakulta MU

Pořičíi 31, 60300 Brno 